\title{
Gambaran Perkembangan Anak Usia Dini Dalam Pembelajaran Daring Selama Pandemi Covid-19
}

\author{
Feti Pratiwi \\ Universitas Semarang, Semarang, 50196, Indonesia \\ feti@usm.ac.id
}

\begin{abstract}
The Description of Early Children's Development in Online Learning During the Covid-19 Pandemic. The Covid-19 pandemic has an impact on the education sector. The Ministry of Education issued a policy for students to study from home (online learning). Online learning protects students from exposure to viruses. However, other impacts will affect student development, especially at PAUD level. Several things related to early childhood development that parents and educators need to pay attention during online learning, namely aspects of the development of religious and moral values, physical-motor, cognitive, language, socio-emotional, and art. The purpose of this study is to describe the development of early childhood in online learning. Through literature study techniques, it is found that online learning affects children's development were some aspects of development have decreased. The level of decline is quite large, namely in the physical-motor and socio-emotional aspects. This is because, early childhood spend more time at home. Fewer opportunities to interact with friends at school or outside the home environment.
\end{abstract}

Keywords: early childhood development, online learning.

Abstrak. Gambaran Perkembangan Anak Usia Dini dalam Pembelajaran Daring Selama Pandemi Covid-19. Pandemi covid-19 berdampak pada sektor pendidikan. Kementrian Pendidikan mengeluarkan kebijakan agar siswa belajar dari rumah (pembelajaran dalam jaringan). Pembelajaran daring melindungi siswa dari paparan virus. Namun, ada dampak lain yang akan mempengaruhi perkembangan siswa, khususnya pada jenjang Pendidikan Anak Usia Dini (PAUD). Beberapa hal terkait perkembangan anak usia dini yang perlu diperhatikan orang tua dan pendidik selama pembelajaran daring yaitu aspek perkembangan nilai agama dan moral, fisik-motorik, kognitif, bahasa, sosial-emosi, serta seni. Tujuan penelitian ini untuk mengetahui gambaran perkembangan anak usia dini dalam pembelajaran daring. Melalui teknik studi literatur, didapatkan hasil bahwa pembelajaran daring mempengaruhi perkembangan anak dimana sebagian aspek perkembangan mengalami penurunan. Tingkat penurunan yang cukup besar yaitu dalam aspek fisik-motorik dan sosioemosional anak. Hal ini karena selama masa pandemi, anak usia dini lebih banyak menghabiskan waktunya di rumah. Kesempatan untuk berinteraksi dengan teman-teman di sekolah atau di lingkungan luar rumah menjadi berkurang.

Kata kunci: perkembangan anak usia dini, pembelajaran daring 


\section{PENDAHULUAN}

Pandemi virus corona (Covid-19), sebuah peristiwa yang sedang terjadi di seluruh dunia sejak awal tahun 2020 dan masih berlangsung sampai sekarang. Virus corona pada umumnya menimbulkan gejala ringan dan sedang pada saluran pernafasan manusia seperti demam, sesak, dan batuk. Gejala ini akan menimbulkan masalah kesehatan yang serius bahkan kematian jika menjangkit orang yang beresiko tinggi. Penyebaran virus corona ini sangat cepat dan meluas melalui interaksi langsung antara orang yang terjangkit virus dan orang sehat. Oleh karena itu, diperlukan usaha untuk memutus mata rantai penyebarannya.

Di Indonesia, pemerintah telah menetapkan kebijakan PSBB (Pembatasan Sosial Berskala Besar) dimana pergerakan orang dibatasi dan juga setiap orang dihimbau untuk mengikuti protokol kesehatan yaitu mencuci tangan, memakai masker, dan menjaga jarak. Kebijakan pemerintah terkait PSBB ini memberikan dampak pada berbagai sektor kehidupan seperti pada sektor ekonomi dan industri, sosial, dan pendidikan. Di sektor pendidikan, pemerintah Indonesia melalui Menteri Pendidikan dan Kebudayaan RI merilis kebijakan terkait pencegahan penularan virus corona di satuan pendidikan dan kebijakan terkait proses belajar selama pandemi, melalui surat edaran No.03 tahun 2020 (Kemendikbud, 2020c) dan Surat Edaran No.4 tahun 2020 (Kemendikbud, 2020d). Kebijakan tersebut mengharuskan seluruh siswa untuk belajar dari rumah, dikenal dengan pembelajaran jarak jauh (PJJ) / pembelajaran dalam jaring (Belajar daring). Peraturan ini diterapkan untuk lembaga sekolah formal maupun informal, mulai dari tingkatan PAUD, SD, SMP, SMA, sampai Perguruan Tinggi. Adanya kondisi pembelajaran jarak jauh daring, di satu sisi memberikan dampak positif karena seluruh siswa terlindungi dari paparan virus corona ini. Namun, dimungkinkan ada dampak lain juga yang akan mempengaruhi aktifitas dan proses pembelajaran siswa, khususnya untuk siswa di jenjang pendidikan anak usia dini (PAUD).

Kita menyadari bahwa pondasi pengembangan kemampuan belajar anak perlu dimulai sedini mungkin. Biasanya di usia 4-6 tahun, orang tua akan memasukkan anak ke sekolah PAUD. Dengan mengikuti kegiatan belajar di PAUD, diharapkan perkembangan fisik dan psikologis anak menjadi lebih optimal sesuai dengan usianya sebagai bekal untuk kesiapan belajar di sekolah dasar kelak. Hal ini sejalan dengan tujuan dari PAUD itu sendiri yaitu sebagai sarana untuk melakukan stimulasi pendidikan dalam membantu pertumbuhan jasmani dan rohani sesuai dengan tingkat pencapaian perkembangan anak, mengoptimalkan perkembangan anak secara holistik dan integratif, dan mempersiapkan sikap, pengetahuan, dan keterampilan anak (Permendikbud, 2014). Dengan melihat kondisi pandemi saat ini, seluruh siswa PAUD pun melaksanakan kegiatan pembelajaran jarak jauh atau pembelajaran daring di rumah masingmasing. Pastinya banyak hal yang perlu diperhatikan oleh orang tua dan pendidik, terutama terkait pertumbuhan dan perkembangan psikologis anak yang meliputi aspek nilai agama dan moral, fisik-motorik, perkembangan kognitif, bahasa, sosial-emosi, serta seni anak.

Berdasarkan Permendikbud (2014) berikut adalah standar nasional pendidikan anak usia dini yang perlu menjadi perhatian dan acuan tenaga pendidik dan orang tua dalam mengoptimalkan perkembangan anak.

Dalam aspek nilai agama dan moral, anak usia dini diharapkan 
mengenal nilai agama yang dianut, mengerjakan ibadah, berperilaku jujur, penolong, sopan, hormat, sportif, menjaga kebersihan diri dan lingkungan, mengetahui hari besar agama, menghormati dan toleran terhadap agama orang lain.

Dalam aspek fisik-motorik, diharapkan anak usia dini mengembangkan kemampuan motorik kasar (meliputi kemampuan gerakan tubuh secara terkoordinasi, lentur, seimbang, lincah, lokomotor, nonlokomotor, dan mengikuti aturan), kemampuan motorik halus (meliputi kemampuan dan kelenturan menggunakan jari dan alat untuk mengeksplorasi dan mengekspresikan diri dalam berbagai bentuk), serta menerapkan hidup sehat dan perilaku keselamatan (meliputi pengukuran berat badan, tinggi badan, lingkar kepala sesuai usia serta kemampuan berperilaku hidup bersih, sehat, dan peduli terhadap keselamatannya.

Dalam aspek kognitif, diharapkan anak usia dini mampu mengikuti kegiatan belajar dan belajar pemecahan masalah (mencakup kemampuan memecahkan masalah sederhana dalam kehidupan sehari-hari dengan cara fleksibel dan diterima sosial serta menerapkan pengetahuan atau pengalaman dalam konteks yang baru), mampu berfikir logis (mencakup berbagai perbedaan, klasifikasi, pola, berinisiatif, berencana, dan mengenal sebab-akibat), dan mampu berfikir simbolik (mencakup kemampuan mengenal, menyebutkan, dan menggunakan konsep bilangan, mengenal huruf, serta mampu merepresentasikan berbagai benda dan imajinasinya dalam bentuk gambar).

Dalam aspek perkembangan bahasa, anak usia dini diharapkan mampu memahami bahasa reseptif (meliputi kemampuan memahami cerita, perintah, aturan, menyenangi dan menghargai bacaan), mampu mengekspresikan bahasa (meliputi kemampuan bertanya, menjawab pertanyaan, berkomunikasi secara lisan, menceritakan kembali yang diketahui, belajar bahasa pragmatik, mengekspresikan perasaan, ide, dan keinginan dalam bentuk coretan), dan mampu mengengenal dan memahami keaksaraan (meliputi pemahaman terhadap hubungan bentuk dan bunyi huruf, meniru bentuk huruf, serta memahami kata dalam cerita).

Dalam aspek sosial-emosional, anak usia dini diharapkan memiliki kesadaran diri (memperlihatkan kemampuan diri, mengenal perasaan sendiri dan mengendalikan diri, serta mampu menyesuaian diri dengan orang lain), memiliki rasa tanggung jawab untuk diri dan orang lain (kemampuan mengetahui hak-haknya, mentaati aturan, mengatur diri sendiri, serta bertanggung jawab atas perilakunya untuk kebaikan sesama), dan memiliki perilaku prososial (kemampuan bermain dengan teman sebaya, memahami perasaan, merespon, berbagi, serta menghargai hak dan pendapat orang lain; bersikap kooperatif, toleran, dan berperilaku sopan).

Dalam aspek seni, anak usia dini diharapkan memiliki kemampuan mengeksplorasi dan mengekspresikan diri, berimajinasi dengan gerakan, musik, drama, dan beragam bidang seni lainnya (seni lukis, seni rupa, kerajinan), serta mampu mengapresiasi karya seni, gerak dan tari, serta drama.

Di sekolah PAUD, para pendidik telah membuat standar proses yang baku untuk kegiatan belajar meliputi perencanaan, pelaksanaan, evaluasi, dan pengawasan pembelajaran. Pelaksanaan pembelajaran sendiri dilakukan melalui kegiatan bermain secara interaktif, inspiratif, menyenangkan, kontekstual dan berpusat pada anak untuk berpartisipasi aktif serta memberikan keleluasaan bagi prakarsa, kreativitas, 
dan kemandirian sesuai dengan bakat, minat, dan perkembangan fisik serta psikologis anak. Keseluruhan standar proses ini dibuat dan diterapkan pada saat pembelajaran di masa normal, dimana pendidik bertatap muka langsung dengan siswa di lingkungan sekolah. Namun di masa pandemi ini, proses belajar (pelaksanaan, evaluasi, dan pengawasan) dilakukan secara daring dimana pendidik tidak bertemu secara langsung dengan siswa. Dengan segala keterbatasan pembelajaran daring ini, para pendidik dan orang tua mengerahkan segala usaha dan upaya agar proses belajar tetap berjalan sebagaimana mestinya sehingga diharapkan tumbuh dan kembang siswa didik tetap sesuai dengan capaian standar nasional pendidikan anak usia dini.

Berdasarkan paparan latar belakang tersebut, peneliti melakukan studi literatur untuk menjawab pertanyaan penelitian: Bagaimana gambaran perkembangan anak usia dini dalam mengikuti kegiatan pembelajaran daring selama pandemi covid-19?.

\section{METODE}

Metode yang digunakan pada penelitian ini adalah literatur review atau studi literatur. Dengan metode ini, peneliti melakukan penelusuran pustaka terhadap jurnal-jurnal penelitian yang sudah ada untuk menjawab pertanyaan penelitian yakni terkait gambaran perkembangan anak usia dini dalam pembelajaran jarak jauh selama pandemi covid-19. Perkembangan ini meliputi perkembangan nilai agama dan moral, perkembangan fisik-motorik, perkembangan kognitif, perkembangan bahasa, perkembangan sosial-emosi, dan seni. Jurnal yang dijadikan referensi adalah hanya jurnal nasional mengingat setiap wilayah / negara memiliki kebijakan dan hambatan yang berbeda dalam pembelajaran daring selama masa pandemi covid-19 ini.

\section{HASIL DAN PEMBAHASAN}

\section{Perkembangan Nilai Agama dan Moral Anak Usia Dini}

Dasar-dasar pendidikan nilai agama dan moral sebaiknya diterapkan pada anak sejak usia dini. Melalui kegiatan di PAUD, anak diajarkan untuk melakukan kebiasaan-kebiasaan baik sesuai dengan tuntunan agama dan normal sosial. Perkembangan nilai agama dan moral yang baik akan membuat anak menunjukkan perilaku baik sesuai dengan tuntutan lingkungan. Selain itu, diharapkan kelak anak sebagai generasi penerus bangsa memiliki karakter baik.

Selama pembelajaran daring di masa pandemi ini, pencapaian nilai agama dan moral anak mengalami penurunan. Salah satu penyebabnya adalah di daerah perkotaan, khususnya yang bersekolah di TKIT / PAUD Islam, orang tua memiliki kendala saat diminta untuk mengembangkan kesadaran nilai agama pada anak dikarenakan orang tua mempercayakan pembelajaran agama sepenuhnya kepada pihak sekolah (Wulandari, 2020).

Di sekolah PAUD, pembelajaran nilai agama ini ditanamkan secara berkelanjutan melalui pembiasaan anak ketika akan melakukan suatu kegiatan. Diharapkan, selama pembelajaran daring orang tua pun menerapkan hal yang sama dengan yang diterapkan di sekolah seperti membaca doa sebelum dan sesudah kegiatan belajar. Selain itu, pembelajaran nilai agama dan moral ini tidak hanya ditanamkan dalam rutinitas ibadah agama tetapi juga melalui berbagai aktifitas anak dalam kehidupan sehari-hari seperti menanamkan rasa kasih sayang pada sesama, bersikap sopan santun, memiliki rasa tanggung jawab, menjaga kebersihan dan ketertiban di lingkungan sekitar. Dengan demikian, orang tua di rumah sebenarnya 
memiliki banyak cara untuk meningkatkan perkembangan nilai agama dan moral anak usia dini ini.

\section{Perkembangan Motorik Anak Usia Dini}

Menurut Payne \& Isaacs (2012), perkembangan motorik merupakan suatu proses dalam hidup manusia yang melibatkan peningkatan dan penurunan kemampuan gerak manusia selama menjalani kehidupannya. Perkembangan motorik terbagi 2 yaitu perkembangan motorik kasar dan perkembangan motorik halus. Perkembangan motorik kasar adalah keterampilan gerak tubuh yang menggunakan otot-otot besar, seperti otot tangan, otot kaki, dan otot seluruh tubuh anak, yang dipengaruhi oleh kematangan anak itu sendiri. Sedangkan perkembangan motorik halus adalah gerakan yang menggunakan otot-otot halus atau sebagian anggota tubuh tertentu (Santrock, 2002).

Kemampuan motorik kasar dan halus ini akan berkembang jika distimulasi atau dilatih. Di sekolah PAUD, kemampuan motorik ini distimulasi melalui berbagai kegiatan yang menggunakan gerak fisik seperti berolah raga, senam, berlari, melompat, meloncat, melempar, menangkap, menendang, dsb. Selain itu, di sekolah siswa melakukan gerakan aktif melalui berbagai jenis media permainan (naikturun tangga, papan seluncur, jembatan gantung, jungkat-jungkit, dsb) dan juga melakukan aktifitas bermain bebas bersama teman-temannya (bermain petak umpet, bermain bola, bermain lompat tali, dsb). Di sekolah juga, anak diberikan aktifitas yang berhubungan dengan keterampilan tangan dan jari-jemari agar otot-ototnya lebih luwes dan terkendali sehingga motorik halusnya berkembang matang seperti meronce, melipat, menggunting dan menempel, meronce, meremas, membuat kerajinan tangan, dsb.

Terkait perkembangan motorik kasar anak usia dini di masa pandemi, Ismawati, dkk.(2020) mengungkapkan bahwa sistem pembelajaran daring nyatanya kurang efektif digunakan untuk menstimulasi perkembangan fisik motorik anak usia dini. Hal ini dapat dilihat dari hasil penilaian kegiatan motorik anak yang semakin hari semakin menurun. Ha ini sejalan dengan yang diungkapkan Wulandari (2020) bahwa ada sedikit penurunan kemampuan motorik anak saat pembelajaran daring. Banyak faktor yang menyebabkan perkembangan motorik anak di masa pandemi ini menjadi kurang berkembang atau bahkan menurun. Hal ini terkait dengan kurangnya stimulasi dari guru dan orang tua di rumah atau stimulasi yang diberikan kurang tepat. Dalam hal ini, karena pembelajaran daring, guru biasanya hanya memberikan tugas yang berkaitan dengan motorik kasar dan motorik halus tanpa langsung melatih dan mengevaluasi setiap gerakan yang dilakukan anak. Oleh karena itu, peran orang tua sangatlah penting. Orang tua perlu ikut melatih dan mengevaluasi setiap gerakan anak agar sesuai dengan tugas yang diberikan. Namun nyatanya, saat anak tidak memperoleh dampingan yang serius dari orang tua, anak akan melakukan setiap tugas dengan alakadarnya.

Selama di rumah, ruang gerak anak di lingkungan rumah pun dibatasi. Frekuensi bermain dengan teman-teman sebayanya pun menjadi berkurang. Kondisi ini menyebabkan anak lebih banyak diam di rumah dan aktifitas yang dilakukan pun kurang bervariasi, sehingga di luar jam pelajaran anak lebih banyak menonton TV atau bermain gadget. Tugas orang tua disini memberikan batasan terhadap penggunaan gawai dan memfasilitasi 
anak melakukan kegiatan gerak aktif yang bervariasi \& menyenangkan misalnya ikut membantu orang tua dalam membereskan rumah seperti menyapu, membereskan tempat tidur, dsb (disesuaikan dengan usia dan kemampuan), orang tua mengajak anak memasak di dapur, berkebun, memandikan kendaraan dan hewan peliharaan, serta membuat jadwal olahraga misalnya senam jasmani, berjalan kaki disekitar rumah, bersepeda, dan olah raga lainnya. Berbagai aktifitas fisik yang dilakukan tersebut secara tidak langsung akan melatih motorik anak sehingga otor-otot tubuhnya kuat dan sehat. Diharapkan saat anak belajar di rumah dan nanti kembali ke sekolah lagi, ketahanan tubuh anak bagus serta siap mengikuti pembelajaran secara langsung.

\section{Perkembangan Kognitif Anak Usia Dini}

\section{Perkembangan kognitif} merupakan kemampuan yang berkaitan dengan proses berfikir, yakni menerima, mengolah, dan memahami suatu informasi. Dunia kognitif anak-anak usia dini / anak prasekolah ialah kreatif, bebas, dan penuh imajinasi (Santrock, 2002). Kemampuan kognitif ini akan berkembang secara bertahap, sejalan dengan pertumbuhan dan perkembangan fisik, susunan syaraf pusat, dan arus informasi yang masuk dari lingkungan sekitar.

Selama pembelajaran daring di masa pandemi ini, perkembangan kognitif anak di PAUD dalam aspek kemampuan memecahkan masalah, kemampuan berfikir simbolik, dan kemampuan berfikir logis berada pada kategori mampu dan cukup mampu (Kurniawati, 2021). Hal ini menunjukkan bahwa meskipun melalui pembelajaran daring, kemampuan kognitif anak tetap bisa ditingkatkan. Tentunya dengan dukungan dari guru sebagai pendidik dan juga orang tua sebagai pembimbing anak belajar di rumah. Guru berusaha untuk menyiapkan materi ajar dan memberikan tugas yang menstimulasi kemampuan kognitif anak serta kehadiran orang tua yang senantiasa membimbing anak selama belajar di rumah.

Walaupun begitu, masih ada beberapa hal yang membuat kemampuan kognitif anak belum berkembang secara optimal sehingga ini yang membedakan perkembangan kognitif antara satu anak dengan anak lainnya. Diantaranya yaitu keterbatasan sarana prasarana belajar daring baik dari pihak guru maupun orang tua. Dikarenakan terbatasnya sarana belajar (lebih banyak menggunakan teks, yaitu melalui aplikasi whatsapp), pelaksanaan pembelajaran menjadi berfokus pada guru, dimana guru memberikan tugas dan murid mengerjakan tugas lalu mengumpulkannya. Begitu juga dengan ketersediaan fasilitas belajar di rumah dan keterlibatan orang tua dalam mendampingi anak belajar akan sangat mempengaruhi pencapaian kemampuan kognitif anak. Adakalanya saat orang tua sibuk bekerja, anak kurang mendapat pendampingan khusus saat belajar. Selain itu, motivasi belajar sangat mempengaruhi minat siswa dalam mengikuti pembelajaran. Anak akan bersemangat saat ia belajar langsung bersama teman-temannya dibandingkan belajar sendiri di rumah.

\section{Perkembangan Bahasa Anak Usia Dini} Menurut Santrock (2014), perkembangan bahasa adalah aspek perkembangan yang terkait dengan kemampuan anak dalam melakukan komunikasi, baik melalui berbicara, menulis, atau menggunakan bahasa isyarat. Di PAUD, kemampuan bahasa meliputi kemampuan bahasa reseptif, bahasa ekspresif, dan keaksaraan. Kemampuan bahasa ini berhubungan 
dengan kemampuan kognitif dan sosioemosional. Dalam hal ini, bahasa berguna sebagai alat komunikasi di lingkungan sosial yang mana diperlukan kemampuan untuk memahami pesan yang disampaikan orang lain baik berbentuk lisan maupun tulisan. Di samping itu, melalui bahasa, ilmu pengetahuan menjadi bertambah. Anak memperoleh ilmu pengetahuan yang berasal dari lingkungan berupa informasi berbentuk bacaan/tulisan maupun yang disampaikan orang lain secara lisan (Direktorat PAUD kemdikbud, 2020).

Di saat pembelajaran daring masa pandemi, Wulandari (2020) mengungkapkan perkembangan bahasa pada anak tidak mengalami penurunan yang besar. Hal ini dikarenakan beberapa faktor, yaitu selama di rumah orang tua (terutama ibu) dan anak menjalin komunikasi secara intens sehingga kemampuan bahasa anak meningkat terutama bahasa ekspresifnya. Selain itu, komunikasi dengan bahasa yang baik dan pembelajaran keaksaraan yang intens dan konsiten di rumah dapat meningkatkan keterampilan bahasa dan literasi dikalangan anak udia dini (Sims \& Coley, 2016 dalam Wulandari 2020).

\section{Perkembangan Sosial-Emosi Anak Usia Dini}

Perkembangan sosial berkaitan dengan kemampuan seseorang dalam berinteraksi dengan orang lain dilingkungan masyarakat. Dengan kemampuan ini, diharapkan seseorang mampu menyesuaikan diri dengan norma dan tradisi dimana ia berada. Kemampuan sosial bisa dilatih sejak usia dini dan akan semakin berkembang saat interaksi dengan orang lain semakin meluas.

$\begin{array}{ccc} & \text { Menurut Erikson } & \text { (2010), faktor- } \\ \text { faktor } & \text { yang } & \text { mempengaruhi }\end{array}$ perkembangan sosial anak usia dini adalah kematangan diri, kondisi keluarga, pendidikan, status ekonomi, kapasitas mental (emosi dan intelegensi). Kemampuan sosial anak berkembang dimulai dari interaksi dan komunikasi dengan anggota keluarga di rumah. Seiring bertambahnya usia anak akan menjalin interaksi dan komunikasi di lingkungan luar rumah salah satunya di lembaga pendidikan yaitu sekolah. Di sekolah anak mulai berinteraksi dengan guru dan teman-teman yang baru dikenalnya.

Berkembangnya kemampuan sosial biasanya beriringan dengan perkembangan emosi. Hal ini karena keduanya saling mempengaruhi, jika salah satunya tidak atau belum berkembang maka akan mempengaruhi aspek yang satunya. Perkembangan emosi sendiri berkaitan dengan kematangan manusia dalam mengelola perasaannya. Kondisi emosi ini melibatkan pikiran dan perubahan fisiologis dalam tubuh, serta ekspresi yang nampak pada perilaku.

Baik kemampuan sosial maupun emosi, keduanya berkembang saat berinteraksi dengan lingkungan. Di masa pandemi ini, kegiatan belajar anak dilakukan di rumah yang mana ini jelas mengurangi interaksi antar siswa atau siswa dengan gurunya. Apalagi siswa PAUD ini sebenarnya masih dalam proses belajar menyesuaikan diri dan menjalin relasi dengan orang lain. Fauziah, dkk (2020) mengungkapkan bahwa selama pembelajaran daring di rumah, anak menunjukkan berbagai macam perubahan perilaku terutama kondisi sosial-emosinya. Untuk psikososial, perubahan sikap tersebut diantaranya adalah sikap pembangkangan, agresi, dan mementingkan diri sendiri. Sedangkan dalam psikoemosional sikap yang ditampilkan dan perubahan sikap yang nampak adalah sikap pemalu dan reaksi emosi yang berlebih. Selain itu, selama 
pembelajaran daring, karena anak jarang berinteraksi dengan teman-temannya sehingga menyebabkan anak menampilkan perilaku yang kurang kooperatif dan kurang menunjukkan sikap toleransi. Kondisi emosinya pun menunjukkan siswa merasa bosan dan sedih karena mereka rindu teman dan gurunya. Tak jarang juga anak mengalami kekerasan verbal dari orang tua karena proses belajar di rumah (Kusuma, 2020). Kondisi lain seperti anak dan orang tua yang kurang menikmati pembelajaran daring membuat emosi keduanya kurang stabil sehingga hasil belajar menjadi kurang optimal (Maula, 2020).

\section{Perkembangan Seni Anak Usia Dini}

Seni merupakan hal yang disukai anak dan menjadi salah satu media bagi guru atau orang tua mengajarkan berbagai hal pada anak sehingga proses belajar menjadi lebih menarik dan menyenangkan, yang kemudian memunculkan efek postitif terhadap perkembangan seni anak. Saat anak-anak memperoleh stimulasi pembelajaran seni, anak juga akan lebih kreatif dan memiliki keterampilan sosial yang lebih baik (Theodotou, 2017 dalam Wulandari 2020). Di masa pembelajaran daring ini, Wulandari (2020) mengungkapkan bahwa aspek perkembangan seni pada anak PAUD tidak mengalami penurunan baik dalam kemampuan menikmati berbagai alunan suara / musik, maupun ketertarikan anak dengan kegiatan seni).

\section{SIMPULAN}

Kegiatan pembelajaran daring di masa pandemi covid-19 mempengaruhi perkembangan anak usia dini. Sebagian besar aspek perkembangan pada siswa PAUD mengalami penurunan seperti pada perkembangan nilai agama dan moral, perkembangan fisik-motorik, perkembangan bahasa, dan perkembangan sosio-emosi. Tingkat penurunan yang cukup besar yaitu dalam aspek fisik-motorik dan sosio-emosional anak. Hal ini karena selama masa pandemi, anak usia dini lebih banyak menghabiskan waktunya di rumah termasuk kegiatan belajar yang dilaksanakan secara daring. Kesempatan untuk berinteraksi dan bermain dengan teman-teman di sekolah atau di lingkungan rumah menjadi berkurang. Hasil studi literatur ini bisa dijadikan referensi untuk mengevaluasi pelaksanaan pembelajaran daring di tingkat PAUD selama masih dalam masa pandemi.

Studi literatur ini memiliki keterbatasan yaitu hasil penelitian sebelumnya terkait pengaruh pembelajaran daring terhadap perkembangan anak usia dini yang bisa dijadikan referensi masih sedikit, khususnya di Indonesia, sehingga studi literatur ini masih bisa dikembangkan jika kedepannya sudah banyak penelitian dengan tema serupa.

\section{REFERENSI}

Direktorat Paud Kemdikbud. (2020). Bermain Bahasa di Rumah dalam Melaksanakan Belajar dari Rumah. Retrieved from https://anggunpaud.kemdikbud.g o.id/images/upload/images/2020 /12_buku_BDR/Bermain_ ahasa_di_Rumah.pdf_20april20. pdf.

Erikson, Erik. 2010. Childhood and Society. Yogyakarta: Pustaka Pelajar

Fauziah, Ismi., dkk. (2020). Analisis Gangguan Psikososial Dan Emosional Aud Di Ra Nurul Iman Medan Belawan Selama 
Jurnal Pendidikan Anak, April 2021, p : 9-18

E-ISSN: 2580-9504

P-ISSN: 2775-4367

Pembelajaran Berbasis Daring. Jurnal Kumara Cendikia, 8(3).

Ismawati, P., Maulida, S., \& Maysaroh, Umi. (2020). Efektifitas

Pembelajaran Daring terhadap Perkembangan Fisik Motorik Anak di RA Nurul Hikmah Ketemas Dungus Puri Mojokerto. Seling: Jurnal Program Studi PGRA, 7(1),2033.

Kemendikbud. 2020b. Peraturan Menteri Pendidikan Dan Kebudayaan Republik Indonesia Nomor 19 Tahun 2020 tentang Perubahan atas Peraturan Menteri Pendidikan dan Kebudayaan Nomor 8 Tahun 2020 tentang Petunjuk Teknis Bantuan Operasional Sekolah Reguler. 2020 b.

Kemendikbud. 2020c. Surat Edaran Nomor 3 Tahun 2020 Tentang Pencegahan Corona Virus Disease (Covid-19) Pada Satuan Pendidikan. Kemendikbud. 2020d. Surat Edaran Nomor 4 Tahun $2020 \quad$ Tentang Pelaksanaan Kebijakan Pendidikan Dalam Masa Darurat Penyebaran Corona Virus Disease (Covid-19).

Kurniawati. (2021). Dampak Pandemi Covid-19 terhadap Perkembangan Kognitif Anak Usia Dini di PAUD Zakiah Akbar Kota Bengkulu (Skripsi). Institut Agama Islam Negeri Bengkulu. Indonesia.

Kusuma, W.S., \& Sutapa, P. (2020). Dampak Pembelajaran Daring
Vol. 7 No. 1 Tahun 2021

DOI:

terhadap Perilaku Sosial Emosiona Anak. Jurnal Obsesi: Jurnal Pendidikan Anak Usia Dini, $5(2), 1635-$ 1643.doi:10.31004/obsesi.v5i2.9 40.

Maula, T.M. (2020). Pengaruh Pembelajaran Berbasis Daring Terhadap Keterampilan Interpersonal Anak Usia Dini, Studi Korelasi pada TK di Wilayah Bandung (Skripsi). Universitas Pendidikan Indonesia. Indonesia.

Payne, V. Gregory., \& Isaacs, Larry D. (2012). Human Motor Development: A Lifespan Approach, $8^{\text {th }}$ Edition. New York: McGraw-Hill.

Peraturan Menteri Pendidikan dan Kebudayaan Nomor 137 Tahun 2014 Tentang Standar Nasional Pendidikan Anak Usia Dini, Jakarta: Kementerian Pendidikan dan Kebudayaan Republik Indonesia.

Santrock, J. W. (2014). Child Development. New York: McGraw Hill Education.

Santrock, J. W. (2002). Child Development. New York: McGraw Hill Education.

Wulandari, H., \& Purwanta, E. (2020). Pencapaian Perkembangan Anak Usia Dini di TK selama Pembelajaran Daring saat Pandemi Covid-19. Jurnal Obsesi: Jurnal Pendidikan Anak Usia Dini, 5(1), 452-462. doi:10.31004/obsesi.v5il.626. 